\title{
Neogene sediments and modern depositional environments of the Zagros foreland basin system
}

\author{
MORTAZA PIROUZ*†, GUY SIMPSON*, ABBAS BAHROUDI $\ddagger$ \&ALI AZHDARI \\ *Université de Genève, Département de Géologie et Paléontologie, Rue des Maraîchers 13, \\ CH-1205 Geneva, Switzerland \\ ‡Exploration Department, Mining Engineering Faculty, University College of Engineering, \\ University of Tehran, North Kargar St, P.O. Box 1439, 957131, Tehran, Iran \\ $\S$ Geological Survey of Iran, Ahwaz Branch, Ahwaz, Kiyan Abad, Shahid Vahabi St, No. 130, \\ P.O. Box 6155656371, Iran
}

(Received 14 October 2010; accepted 4 February 2011; first published online 1 June 2011)

\begin{abstract}
A sedimentological investigation of the Neogene deposits of the Zagros foreland basin in SW Iran reveals a continuous and largely gradational passage from supratidal and sabkha sediments at the base (represented by the Gachsaran Formation) to carbonates and marine marls (Mishan Formation with basal Guri carbonate member) followed by coastal plain and meandering river deposits (Agha Jari Formation) and finally to braided river gravel sheets (Bakhtyari Formation). This vertical succession is interpreted to represent the southward migration of foreland basin depozones (from distal foredeep and foredeep to distal wedge-top and proximal wedge-top, respectively) as the Zagros fold-thrust belt migrated progressively southward towards the Arabian foreland. This vertical succession bears a striking similarity to modern depositional environments and sedimentary deposits observed in the Zagros region today, where one passes from mainly braided rivers in the Zagros Mountains to meandering rivers close to the coast, to shallow marine clastic sediments along the northern part of the Persian Gulf and finally to carbonate ramp and sabkha deposits along the southeastern coast of the Persian Gulf. This link between the Neogene succession and the modern-day depositional environments strongly suggests that the major Neogene formations of the Zagros foreland basin are strongly diachronous (as shown recently by others) and have active modern-day equivalents.
\end{abstract}

Keywords: Zagros, foreland basin, clastic sediments, Neogene, modern depositional environment.

\section{Introduction}

The Zagros chain is among the most famous geological provinces in the world, renowned for its spectacular whaleback anticlines, extreme seismic activity and its textbook modern carbonate system, in addition to containing abundant oil and gas reserves. Many studies have covered the Zagros in terms of petroleum research (Ala, Kinghorn \& Rahman, 1980; Ala, 1982; Bordenave \& Burwood, 1990; Ghasemi-Nejad, Head \& Naderi, 2009), structural geology (Stocklin, 1968; Falcon, 1974; Colman-Sadd, 1978; Bahroudi \& Koyi, 2003, 2004; McQuarrie, 2004; Sherkati \& Letouzey, 2004; Sepehr \& Cosgrove, 2004; Molinaro, Zeyen \& Laurencin, 2005; Lacombe et al. 2006, 2007; Mouthereau et al. 2007; Aubourg et al. 2008; Jahani et al. 2009), basin evolution (Alavi, 2004, 2007) and carbonate stratigraphy (e.g. from the OligoMiocene Asmari limestone and older units, e.g. Szabo \& Kheradpir, 1978; Nadjafi et al. 2004; Vazirimoghaddam, Kimiagari \& Taheri, 2006; Razin, Taati \& van Buchem, 2010), while the younger mainly clastic Neogene deposits have received less investigation, at least until recently (Homke et al. 2004; H. Emami, unpub. Ph.D. thesis, Univ. de Barcelona, 2008; Fakhari

$\nmid$ †uthor for correspondence: mortaza.pirouz@unige.ch et al. 2008; Khadivi et al. 2010). This is probably because most petroleum is held within older units and because the younger sediments tend to be relatively homogeneous and more difficult to date and map as coherent units. This is unfortunate because the Neogene deposits form part of an exceptionally well-exposed foreland basin succession that records the evolving landscape along with local climate and tectonics in the region over the last 20 million years.

The purpose of this paper is to document in some detail the sediments composing the Neogene foreland basin in the Zagros, based largely on our own field investigation across the region over the last few years. In doing so, we aim to place the various deposits observed within the context of foreland basin depozones (see also Alavi, 2004, 2007), as already established for many other foreland basin systems (e.g. Sinclair et al. 1991; DeCelles et al. 1998; Mutti et al. 2003). The Zagros system offers an advantage over many other foreland basins in that it is currently active and has been so for a considerable time period. Thus, it provides an ideal case where one can investigate the transition in time and space between the modern-day palaeoenvironments (e.g. wedge-top, foredeep) and older deposits that were progressively buried and incorporated into the orogen as it widened through time. Our investigation shows a strong link between the various Neogene deposits and 
the modern depositional environments, which suggests that the previously described Neogene formations are likely to be strongly diachronous. Indeed, this is consistent with several recent studies that have shown that the age of the Agha Jari and Bakhtyari formations vary across the region (Homke et al. 2004; H. Emami, unpub. Ph.D. thesis, Univ. de Barcelona, 2008; Fakhari et al. 2008; Khadivi et al. 2010; see also Saura et al. 2011).

\section{Geological setting}

The Zagros is a mountain belt that extends more than $2000 \mathrm{~km}$ between the Hormuz strait and NW Iran. The tectonic history of the Zagros can be divided into four main stages (e.g. Stöcklin, 1968, 1974, 1977; Adamia et al. 1981; Berberian \& King, 1981; Koop \& Stoneley, 1982; Sengor, 1990; Beydoun, 1991; Beydoun, Clarke \& Stoneley, 1992; Sepehr \& Cosgrove, 2004):

(1) Early Palaeozoic stable passive margin. During this period the region was part of a stable passive margin of Gondwana bordering the Palaeo-Tethys ocean to the north (Berberian \& King, 1981). The oldest wellknown sediment deposited during this stage is the Lower Cambrian Hormuz salt (R. A. Player, unpub. Ph.D. thesis, Univ. Reading, 1969; Kent, 1970), which occurs mainly east of the Kazerun fault zone, where it can attain a thickness of $2000 \mathrm{~m}$ (Falcon, 1974; Beydoun, Clarke \& Stoneley, 1992; Talbot \& Alavi, 1996; Sepehr \& Cosgrove, 2005).

(2) Permo-Triassic rifting. Extension during this time led to opening of the Neo-Tethys ocean separating the Iranian microplate to the north from the Arabian plate to the south. At the same time the Palaeo-Tethys basin to the north was closed. During this period a considerable amount of sediments, dominated by carbonate and volcanic rocks, were deposited and many NW-SEtrending normal faults were active.

(3) Jurassic passive continental margin. During this time a passive margin continued to develop on the northern part of the Arabian plate. However, the characteristics of this margin vary considerably in an $\mathrm{E}-\mathrm{W}$ direction, with major changes coinciding with $\mathrm{N}-$ $\mathrm{S}$ structures such as the Kazerun and Izeh fault zones. To the east, in the Fars region where the margin was relatively elevated, mainly shallow marine carbonates and marls were deposited. In the Lorestan region further to the west, the margin was deeper and contains deep water sediments (Setudehnia, 1978; Sepehr \& Cosgrove, 2004).

(4) Cretaceous-Recent subduction and collision. Subduction of the Neo-Tethys ocean during Cretaceous time (which possibly initiated even earlier) eventually led to continent-continent collision between the Arabian and Iranian plates, which began some time in the middle Tertiary, though the exact timing is still debated (e.g. see Agard et al. 2005; Mouthereau et al. 2007; Allen \& Armstrong, 2008; Ballato et al. 2011). Collision led to deformation, uplift and erosion of the Arabian passive margin sequence in the Zagros Mountains, while towards the south a foreland basin was formed. The Zagros Mountains and the foreland are currently seismically extremely active. Recent GPS measurements indicate that the Arabian plate continues to move northwards relative to the Iranian microplate at rates of $20 \pm 5 \mathrm{~mm} \mathrm{yr}^{-1}$ (Tatar et al. 2002; Blanc et al. 2003; Nilforoushan et al. 2003; Allen, Jackson \& Walker, 2004; Allen et al. 2006; Vernant et al. 2004; Rielinger et al. 2006; Walpersdorf et al. 2006).

At the present day, the Zagros region can be divided into three main tectonic units. From north to south they are the Urumieh-Dokhtar volcanic belt, the Sanandaj-Sirjan metamorphic belt and the Zagros fold-thrust belt. The latter two units are separated by the Main Zagros Reverse Fault. The Zagros fold-thrust belt can itself be divided into two main zones, the High Zagros Imbricated Zone to the north and the Zagros Simply Folded Belt, separated by the High Zagros Fault. The Zagros Mountain Frontal Fault separates the Simply Folded Belt from the Dezful Embayment, while the Zagros Foredeep Fault separates the Dezful Embayment from the undeformed foreland to the south (Fig. 1). In addition to these tectonic subdivisions, the Zagros region can be separated into three main geological provinces. From west to east, these are the Lorestan, Khuzestan (Izeh Zone and Dezful Embayment) and Fars provinces. The boundaries between these provinces coincide with major $\mathrm{N}-\mathrm{S}$ faults that were formed before collision (Bahroudi \& Talbot, 2003).

\section{Modern Zagros foreland basin}

We begin our study by summarizing the main features of the foreland basin as observed today in the Zagros. Investigating the modern system is important because it provides a key to understanding the ancient deposits. The modern foreland basin can be broadly subdivided into wedge-top and foredeep following the classification scheme of DeCelles \& Giles (1996). No forebulge is clearly distinguishable on the basis of present-day topography. The boundary between wedge-top and foredeep coincides with the current deformation front, which occurs somewhere near the northern coastline of the Persian Gulf before continuing northwestward into terrestrial Iraq (Fig. 2).

In the eastern part of the Zagros within the Fars region, the wedge-top consists of a series of sub-parallel, roughly $\mathrm{E}-\mathrm{W}$-trending anticlines and synclines with wavelengths of $20-40 \mathrm{~km}$ and topographic relief of approximately $1500 \mathrm{~m}$ (Mouthereau, Lacombe \& Meyer, 2006; Mouthereau et al. 2007). Major rivers in this region are rare (but include the Mand, Heleh and Kal rivers) and are ephemeral (Fig. 2). They wind their way across the fold belt, avoiding most major structures by passing around the noses of plunging anticlines before eventually reaching the Persian Gulf in the south. In the western part 


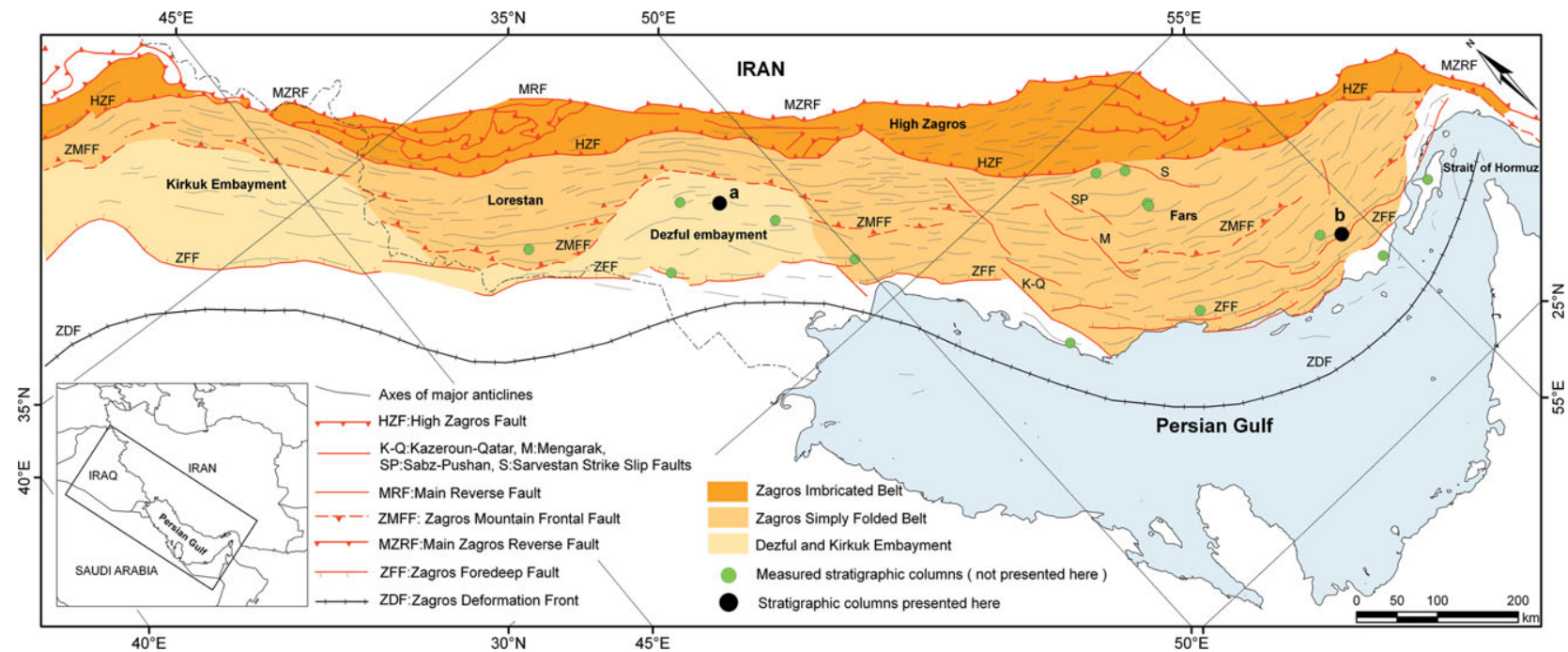

Figure 1. (Colour online) Structural setting and tectonic subdivisions of the Zagros fold-thrust belt and foreland basin of southwestern Iran and Northern Iraq (after Berberian, 1995). Also indicated are the positions of several major faults and the locations of the stratigraphic columns (indicated with black dots labelled a and b) shown in Figure 6.

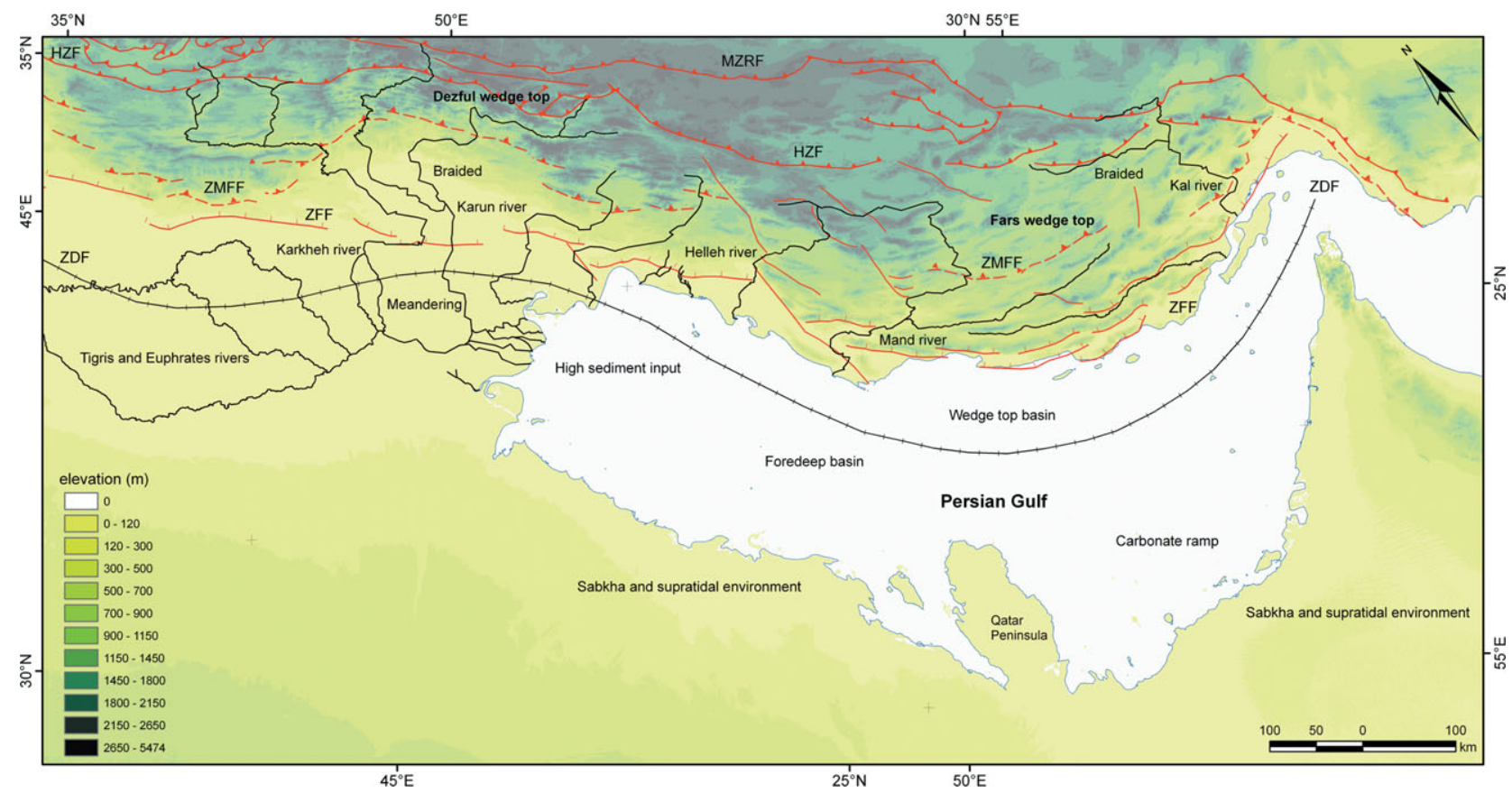

Figure 2. (Colour online) Zagros foreland basin divisions and modern sedimentary environments. MZRF - Main Zagros Reverse Fault; HZF - High Zagros Fault; ZMFF - Zagros Mountain Frontal Fault; ZFF - Zagros Foredeep Fault; and ZDF - Zagros Deformation Front.

of the Iranian Zagros within the Dezful Embayment, the wedge-top can be divided into two main regions. North of the Zagros Mountain Frontal Fault, the wedgetop consists of mainly mountainous terrane reaching elevations of close to $3000 \mathrm{~m}$. This region mainly undergoes erosion but local deposition does occur along some major river valleys which cut transversely to the NW-SE-trending structures. These rivers are either braided (Fig. 3a) or cut directly into bedrock along deep river gorges. South of the Zagros Mountain Frontal Fault the mountainous topography gives way to an extensive, low relief, depositional flood plain broken only occasionally by linear ridges associated with growing anticlines. In this region, the rivers that exit the mountains to the north eventually become meandering (Fig. 3b) before reaching the northwestern corner of the Persian Gulf(Fig. 3c). The major river systems draining this part of the wedge-top basin are the Karkheh and Karun rivers and contain water all year round (Fig. 2).

The foredeep of the Zagros foreland basin is marine where it coincides with the Persian Gulf, while it is non-marine in Iraq and the southwestern corner of Iran. The terrestrial part of the foredeep consists of an extensive, low relief flood plain occupied by several major meandering rivers (such as the Tigris and Euphrates rivers) that flow mainly axially along the foredeep, parallel to the deformation front, before eventually entering into the Persian Gulf (Fig. 2). 

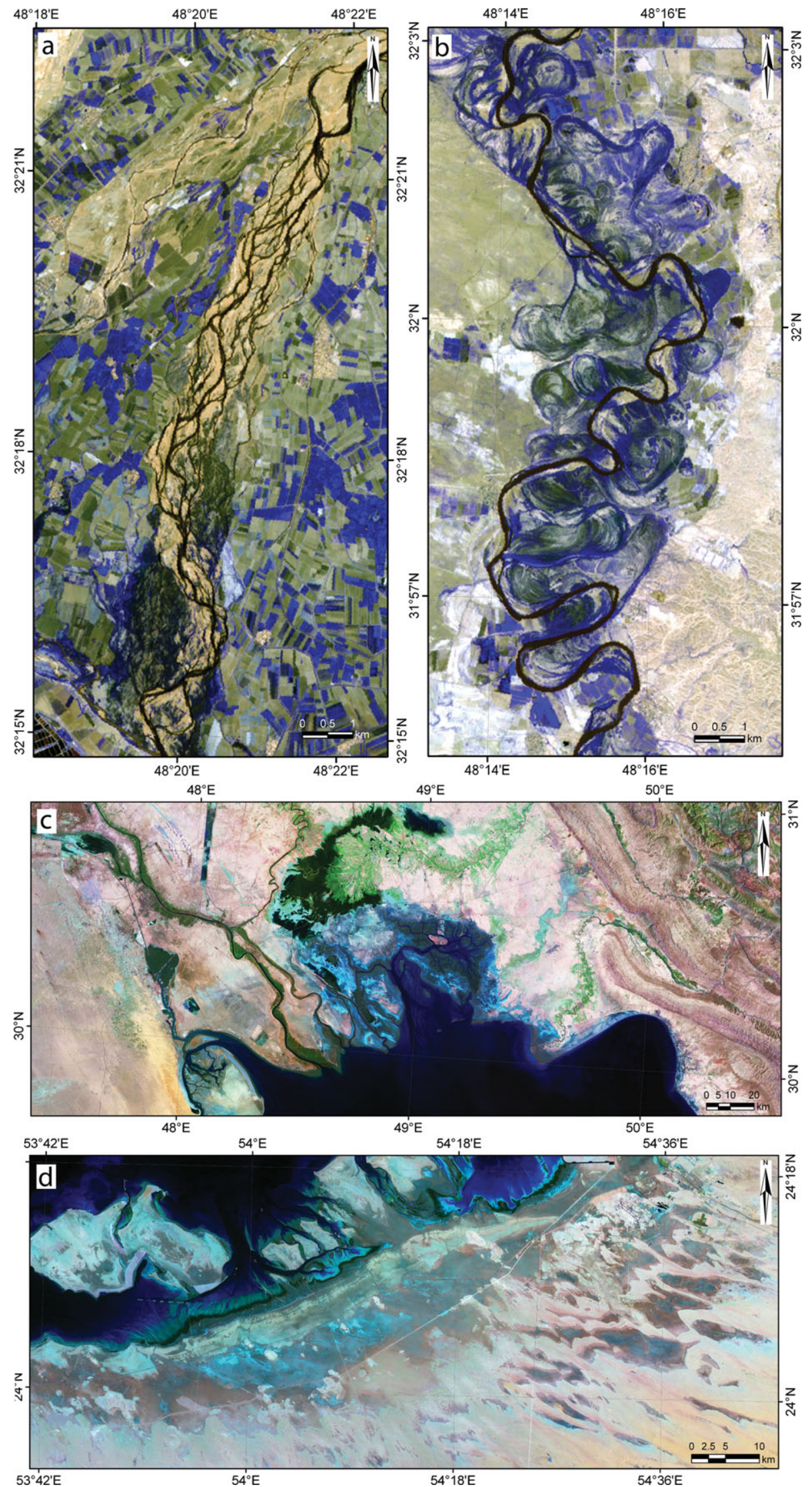

Figure 3. (Colour online) Satellite images of different modern sedimentary environments in the Zagros foreland basin. (a) Braided river system in the northern Dezful area. (b) Meandering river system in the southern part of the Dezful Embayment. (c) Coastal plain and shallow marine environments where several major meandering rivers enter the northwestern corner of the Persian Gulf. (d) The southern coast of the Persian Gulf east of the Qatar Peninsula showing supratidal and sabkha environments in light blue (mid grey). Note also sand dunes related to the Shamal wind. 
The Persian Gulf itself is a major semi-closed basin approximately $1000 \mathrm{~km}$ long and 85 to $350 \mathrm{~km}$ wide. The Persian Gulf lacks major wave swell and has small tides. The median water depth is $35 \mathrm{~m}$ and a maximum depth of 100 m occurs in the Strait of Hormuz (Emery, 1956; Purser \& Seibold, 1973). The northern part of the Persian Gulf includes a belt affected by PlioPleistocene Zagros folding, faulting and salt diapirism, and thus is part of the wedge-top, whereas only the southern portion can be considered proper foredeep. The northern shoreline is mostly rocky and linear with estuaries and flood plains that are associated with rivers draining the Zagros fold belt to the north. The southern shoreline is mostly linear but is broken by the Qatar Peninsula, which has an important role in the sedimentary environment on either side (Purser \& Seibold, 1973). Towards the east of the peninsula occurs one of the classic modern-day carbonate-evaporite systems of the world. From south to north it includes lagoon, restricted shelf, open shelf, ramp and basin (Fig. 2). The coast of the United Arab Emirates is a shallow $(<20 \mathrm{~m})$, high-energy environment where clastic input is low and bioclastic and oolitic sands dominate (Purser \& Seibold, 1973). The deeper parts of the Persian Gulf to the north have a low to moderate energy where fine-grained argillaceous and micritic sands accumulate (Houbolt, 1957; Purser \& Seibold, 1973). On the western side of the Qatar Peninsula, the basin has a high aeolian sediment supply (owing to the Shamal wind), which is reworked by tidal currents in a shallow marine environment. The aeolian terrigenous sediments consist of fine sand to clay with high contents of carbonate particles (Foda, Khaiaf \& Al-kadi, 1985). The northwestern corner of the Persian Gulf has a high clastic sediment input owing to the presence of major river systems draining the Zagros mountain belt to the north (Figs 2, 3c). In some places on the southern coast of the Persian Gulf, quartzite dunes are presently entering the Persian Gulf (Fryberger, Al-Sari \& Clisham, 1983).

\section{Neogene foreland basin deposits}

In this Section we provide a detailed description of the sedimentary deposits that compose the Neogene foreland basin. This Section is based mainly upon our own studies during which we have measured a total of 16 stratigraphic columns (see Fig. 1) at metre-scale resolution, amounting to a total stratigraphic thickness of approximately $35 \mathrm{~km}$. Two of these stratigraphic columns, one located in the Dezful province and the other in the Fars region, are presented in Figure 6. Our description begins with the Gachsaran Formation, which is the first deposit after the Asmari limestone that provides evidence for significant clastic input related to collision. In the following Section we largely sidestep the issue of time, placing greater emphasis on depositional facies (Reading, 1986, pp. 20-342; Reineck \& Singh, 1980, pp. 257-456). The reason for this is partly because we currently do not have good time constraints and partly because, based on our field study, we suspect that the Neogene formations' boundaries must be diachronous (as shown recently by Homke et al. 2004; H. Emami, unpub. Ph.D. thesis, Univ. de Barcelona, 2008; Fakhari et al. 2008; Khadivi et al. 2010). This point will be elaborated upon in greater detail in Section 5.

\section{4.a. Gachsaran Formation}

The Gachsaran Formation is one of the most important formations in the Zagros foreland basin. On the one hand, it acts as a cap rock for the Asmari Formation petroleum reservoir and on the other hand, it forms a detachment level above which the overlying formations can be decoupled from deeper structures. Different sedimentary facies and sudden changes in the thickness have added to its complexity (O'Brien, 1957; Dunnington, 1968; Stocklin, 1968; Bahroudi \& Koyi, 2004). This formation extends across the whole of the Zagros foreland basin (Fig. 4a) and consists of three main lithofacies associations in the 16 sections studied.

\section{4.a.1. GS1}

This lithofacies association consists of a basal conglomerate bed overlain by red mudstones along with siltstone interbeds, sandstone bodies and bioclastic limestones. The basal conglomerate is massive to faintly bedded, grain supported, well cemented and includes in situ marine fossils (Fig. 5a). The clasts of the conglomerate have a high sphericity, are medium sized $(3-8 \mathrm{~cm})$, well sorted and well rounded. Lenticular sandstones exhibit cross-bedding and are less than $2 \mathrm{~m}$ thick. This lithofacies association is known as the Razak Formation in the High Zagros region and the interior Fars area (Fig. 4a). The general thickness of this formation decreases towards the south away from the Zagros mountain belt where it may be tens of metres to $750 \mathrm{~m}$ thick.

\section{4.a.2. $G S 2$}

This unit, which crops out mainly in the coastal Fars and northern part of Persian Gulf, consists of about $250 \mathrm{~m}$ of carbonate rocks, green marls, mudstones and evaporite deposits. This unit can be subdivided into three main sub-facies $(\mathrm{GS} 2 \mathrm{a}-\mathrm{c})$. The GS2a sub-lithofacies association includes gypsum, anhydrite, red and green marl and marly limestone interbeds, and is widely known as the Chehel Member. This sub-unit contains abundant brachiopods, miliolids, globigerinids and Peneroplis evolutus. The next sub-unit (GS2b), known as the Champeh Member, consists of almost $120 \mathrm{~m}$ of fossiliferous limestones, dolomite and resistant green marls that exhibit sharp morphologies in outcrop. This sub-unit contains Peneroplis farsensis, Miogypsina sp., Dendritina rangi, rotalids and bryozoans. The next sub-lithofacies association (GS2c), known as the Mol Member, includes approximately $60 \mathrm{~m}$ of easily erodible red, grey and green mudstones and also evaporitic 

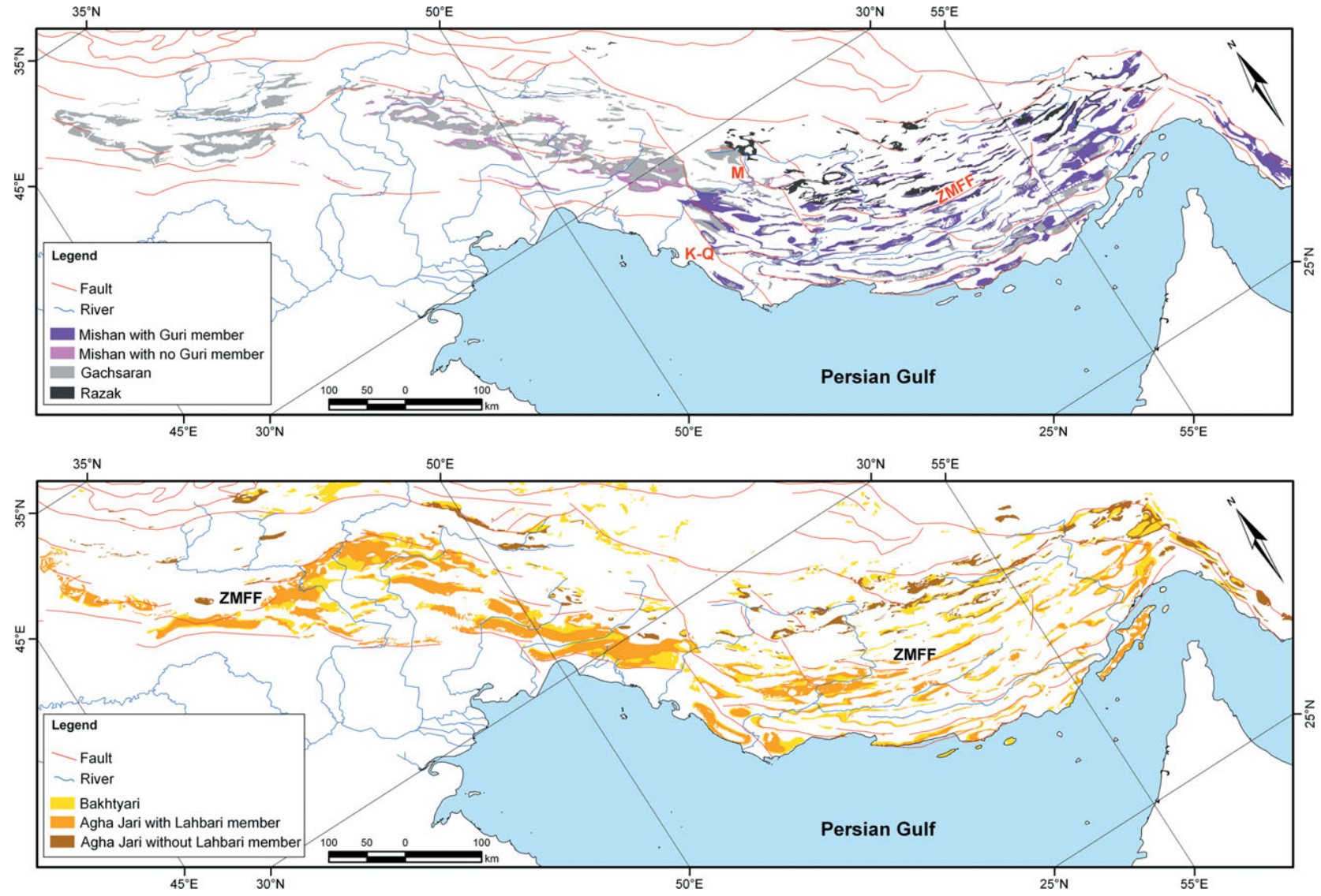

Figure 4. (Colour online) Maps showing the distribution of major Neogene formations in the Zagros foreland basin based on published geological maps. (a) Distribution of the Razak, Gachsaran, Guri Member and Mishan units. (b) Distribution of the Agha Jari and Bakhtyari units. K-Q - Kazeroun-Qatar fault; M - Mengarak fault; ZMFF - Zagros Mountain Frontal Fault.

sediments. This sub-lithofacies association contains Miogypsina sp., Peneroplis farsensis, Taberina sp., rotalids and bryozoans (James \& Wynd, 1965).

\section{4.a.3. $G S 3$}

The last major lithofacies association of the Gachsaran Formation includes abundant gypsum, salt, anhydrite and also coloured marls (Fig. 5b). This unit is extensive in the southern part of the Persian Gulf and western part of the Zagros foreland basin where it may attain a thickness of $1500 \mathrm{~m}$. This sub-lithofacies association is dominated by salt layers in the extreme eastern part of the Zagros (Strait of Hormuz) where it is called the Qeshm Formation. This lithofacies association is commonly highly deformed owing to its ductile nature related to abundant evaporites.

\section{4.a.4. Interpretation}

The Razak Formation (GS1) is a synorogenic deposit that was most likely produced by a fluvial system, probably braided rivers, in a coastal plain environment. This clastic lithofacies association (GS1) is replaced by an open shallow marine carbonate system (GS2) in the eastern part of the Zagros foreland basin in the Fars area. Also, this clastic system (GS1) is replaced by supratidal and sabkha depositional environments (GS3) in the western and extreme eastern parts of the Zagros foreland basin (Dezful and Bandar Abbas regions, respectively) and the southern part of the Persian Gulf (Fig. 4a).

\section{4.b. Mishan Formation}

The Mishan Formation consists of easily erodible green and grey marls with thin ridge-forming carbonates, oyster beds and shelly detrital limestones. It becomes conglomeratic near the top in some places. This formation also includes a massive limestone bed, occasionally with thin green marl interbeds, close to the bottom, which is commonly called the Guri Member. The Guri Member does not exist in the western part of the Zagros foreland basin (Fig. 4a). It is thin in the eastern part of Dezful area (tens of metres) and increases in thickness towards the ESE where it may reach a thickness of $1600 \mathrm{~m}$ in the Bandar Abbas area. Three main lithofacies associations can be identified (MN1-3).

\section{4.b.1. MN1}

The lower lithofacies association consists of evaporite deposits, red mudstones, sandy-limestones, limestones and green marls. In its upper part, this unit is mostly dominated by green marl and coquina limestone interbeds containing bryozoans, ostracods and foraminifera. The foraminifera are essentially small benthic species 

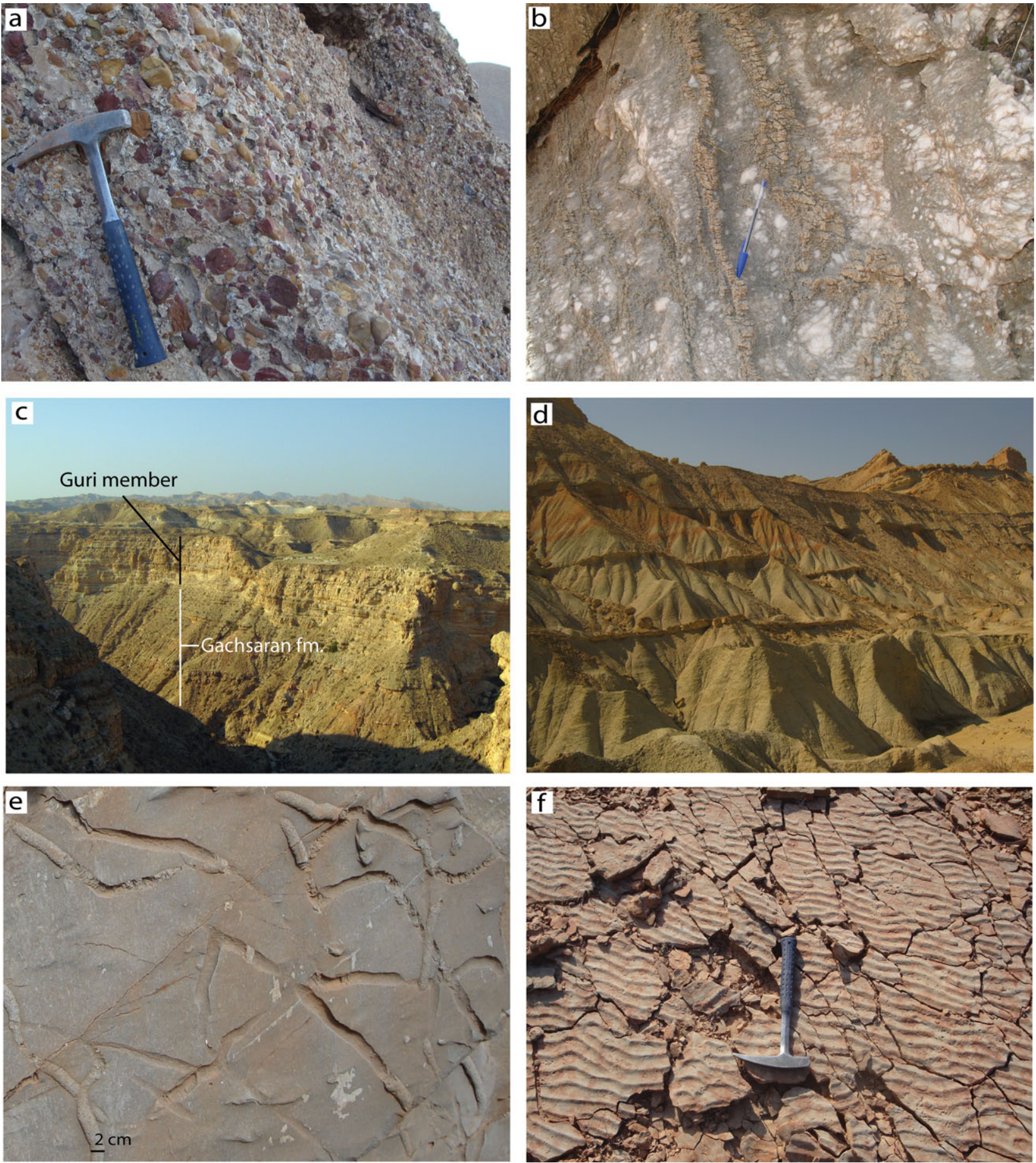

Figure 5. (Colour online) Field photos of the Neogene foreland basin sediments in the Zagros. (a) Basal conglomerate of the Razak Formation (lower part of lithofacies association GS1). (b) Gypsum and evaporate layers of the Gachsaran Formation (GS3). (c) Massive limestone of the Guri Member overlying the Gachsaran Formation (MN2). (d) Easily erodible green marls of the Mishan Formation (MN3). (e) Horizontal bioturbation in a sandstone bed in the lower part of the Agha Jari Formation (AJ1). (f) Wave ripple marks in a mottled sandstone interbed (AJ1).

with some larger Miogypsina spp. The benthic foraminifera include Miogypsina globulina, anomalinids, textulariids, rotalids, asterigerinids and Clavulina sp. Planktonic foraminifera are extremely rare but consist of Globigerinoides trilobus, G. bisphericus, G. sacculifer, G. immaturus, G. quadrilobatus, G. parawoodi, Globigerinoides spp., Globoquadrina cf. praedehiscens, Catapsydrax martini, Globoturborotalia woodi, Globigerina cf. praebulloides, G. cf. eamesi and
Globigerina spp. The thickness of this unit is variable from several metres to $400 \mathrm{~m}$, increasing towards the southeast (Fig. 6a, b).

\section{4.b.2. $M N 2$}

The next lithofacies association, commonly known as the Guri Member, consists of massive to thickbedded, brownly weathered, biosparite and biomicrite limestones that occur mainly in the Fars area where 

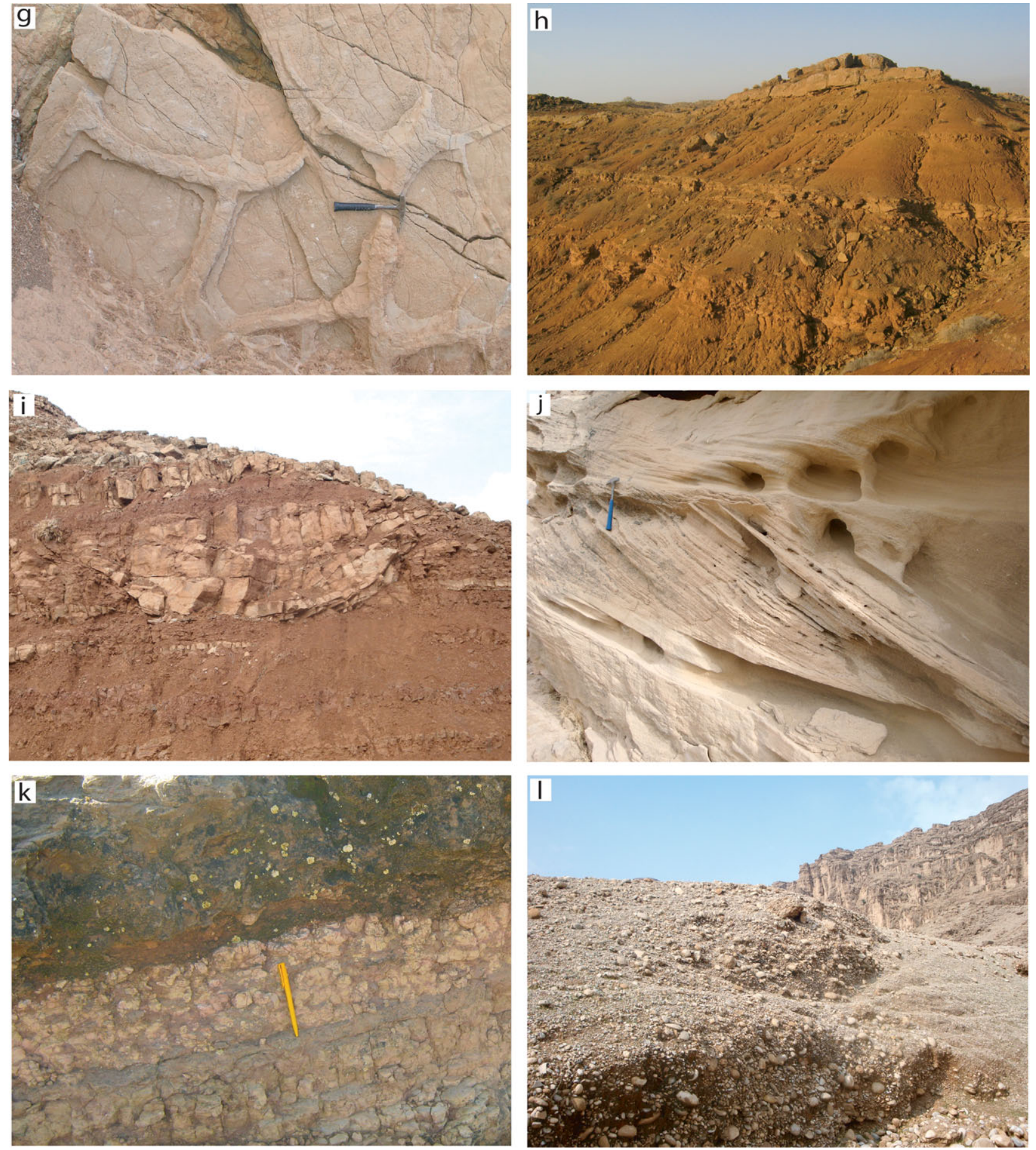

Figure 5. (Continued) (g) Mud cracks in the Agha Jari Formation (AJ1). (h) Repetition of sheet-like sandstone bodies and red flood plain silty-marls (AJ2). (i) Lenticular channel type sandstone body enclosed within red silty-mudstones (AJ2). (j) Cross-bedded sandstone in the Agha Jari Formation (AJ2). (k) Palaeosoil horizon with calcite nodules overlain by a sandstone channel (AJ2). (1) Massive gravel conglomerate of the Bakhtyari Formation (BK1a). Length of rock hammer is $33 \mathrm{~cm}$ and pen is $15 \mathrm{~cm}$.

it may reach a thickness of up to $1200 \mathrm{~m}$ (Fig. 5c). This unit consists of abundant benthic foraminifera and coral. The identified microfauna include Operculina complanata, Nephrolepidina sp., Miogypsina sp., Flosculinella bontangensis, Dendritina $\mathrm{cf}$. rangi, Taberina malabarica and Neoalveolina (Borelis) melo (James \& Wynd, 1965). This unit also contains planktonic foraminifera, including Globigerinoides triloba, $G$. sacculifera, G. cf. rubra and Orbulina universa (James \& Wynd, 1965). The MN2 lithofacies association is reefal in many places in the eastern Fars, whereas in the west it occurs as interbedded resistant limestone separated by thin green marls. This unit makes a salient morphology in the Fars area (Fig. 6b).

\section{4.b.3. $M N 3$}

The last lithofacies association tends to be dominated by thick-bedded to massive green marls with occasional thin limestone interbeds $(<2 \mathrm{~m})$ and thin oyster beds 
a. Dezful region

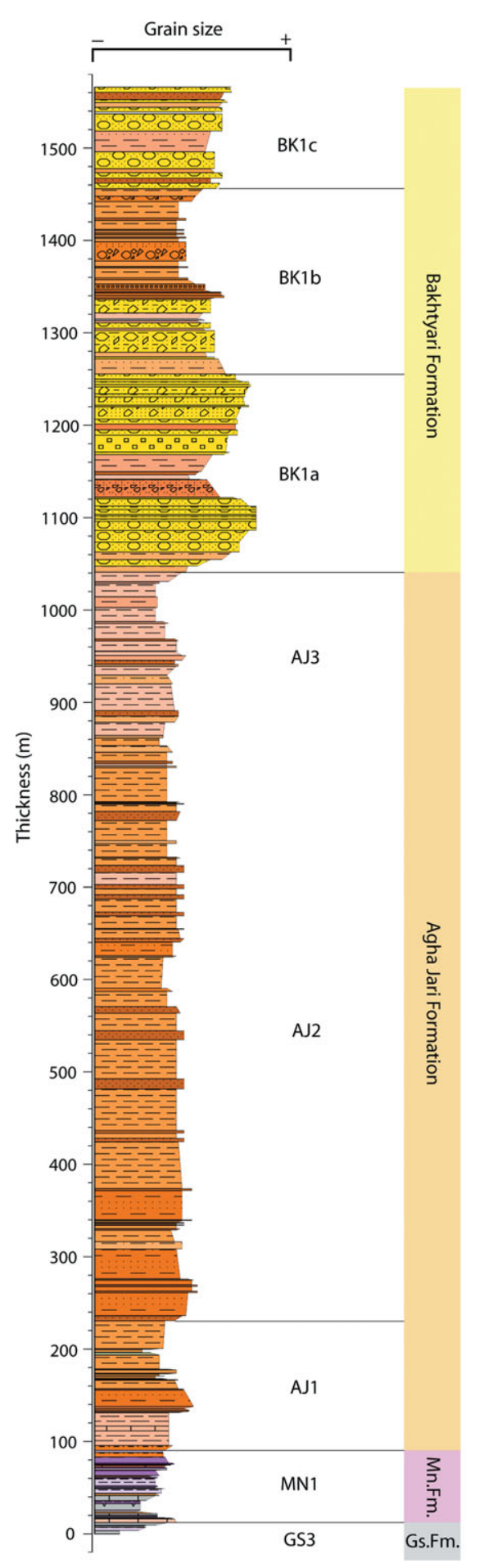

\section{b. Fars region}

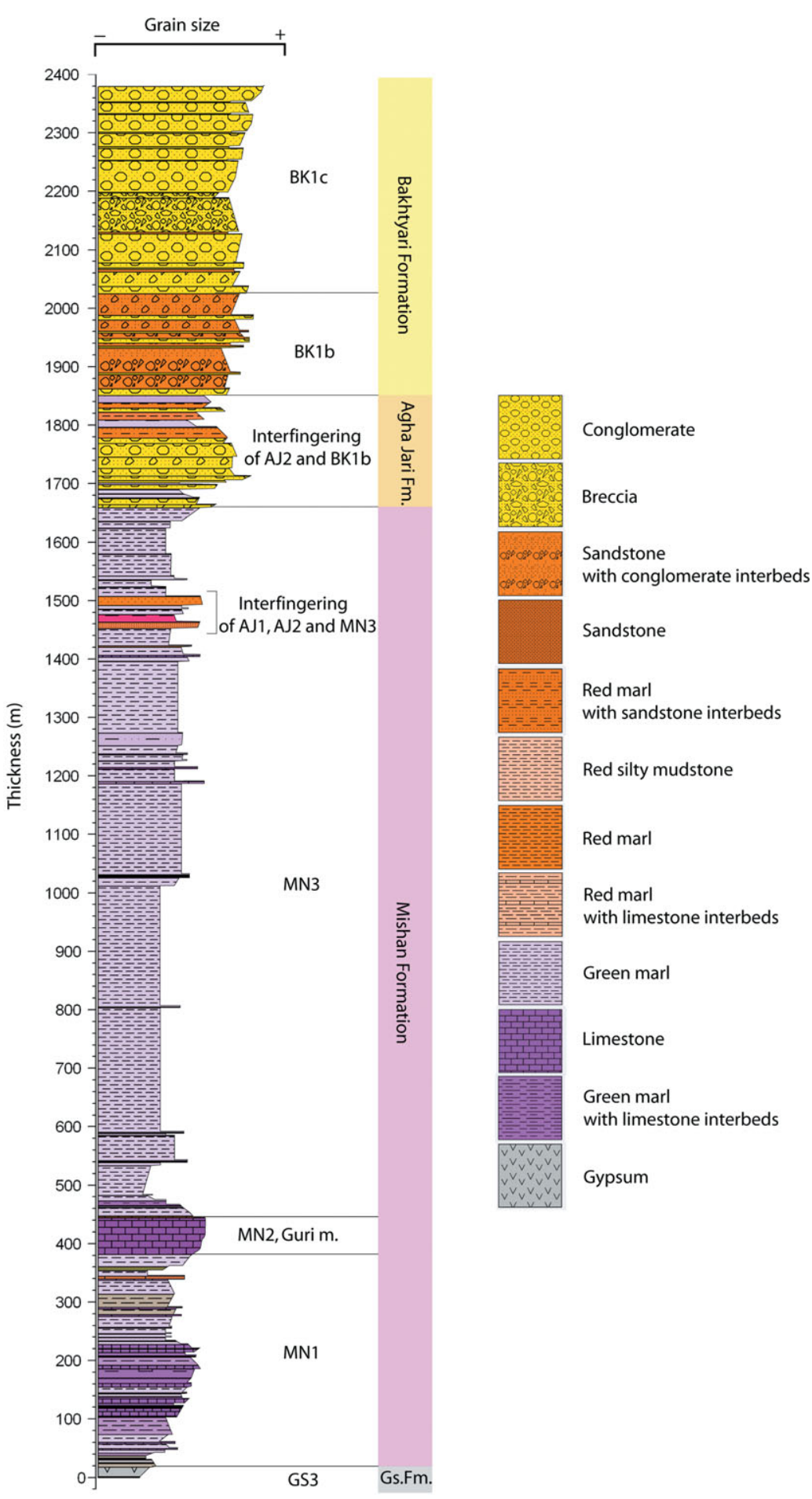

Figure 6. (Colour online) Measured stratigraphic columns through the post-Asmari Neogene formations in the Dezful (a) and Fars (b) regions (only the upper part of the Gachsaran is shown). Also shown are major lithofacies associations as discussed in the main text. The location of these stratigraphic profiles is shown on Figure 1.

$(<0.5 \mathrm{~m})$ (Fig. 5d). The thickness of this unit increases towards the SSE in the Fars area where it can be up to $700 \mathrm{~m}$ thick (Fig. 6b).

\section{4.b.4. Interpretation}

The Mishan Formation is interpreted to be deposited in a shallow marine environment within a generally upward-deepening (transgressive) trend. The MN1 lithofacies association probably represents a lagoon or similar restricted environment, which was sometimes replaced by supratidal and sabkha environments. The next lithofacies association (MN2) containing the Guri Member reefal limestone is interpreted to be deposited in a low-energy shallow carbonate system that deepened towards the north. The MN3 
lithofacies association dominated by fine-grained marls is interpreted to be the deeper open marine part of the carbonate system.

\section{4.c. Agha Jari Formation}

The Agha Jari Formation consists of repetitively interbedded resistant sandstone beds separated by easily erodible mudstones. The proportion of mud-rich to sand-rich units is typically approximately $75 \% / 25 \%$. This formation is the thickest formation in the Zagros foreland basin (James \& Wynd, 1965; Setudehnia, 1972; Favre, 1974; Motiei, 1993).The thickest part is usually situated along the axis of synclines and in front of major thrusts. The overall thickness of the formation decreases towards the southeast away from Zagros Mountains where it may be more than $3000 \mathrm{~m}$ thick (Fig. 4b). Three main lithofacies associations can be identified (AJ1-3).

\section{4.c.1. AJ1}

In the lower part of the Agha Jari Formation, sandstone units tend to be thin $(<1 \mathrm{~m})$, parallel laminated and laterally extensive over hundreds of metres. These units display abundant (both horizontal and vertical) bioturbation (Fig. 5e), along with ripple marks (Fig. 5f), mud cracks (Fig. 5g), load casts, unidirectional flute casts and oxidized plant fragments. Flaser bedding and small (centimetre)-scale climbing ripples are also sometimes observed, both of which contain mud drapes. The sandstones are fine-grained, well-sorted litharenites containing sub-rounded grains with low sphericity. Lithic fragments consist mainly of carbonate clasts and occasional shell fragments derived from older carbonate units. The sandstones do not contain any 'in place' fossils except in the more proximal part of the basin where the Agha Jari Formation overlies the Razak Formation (Khadivi et al. 2010). The sandstones are separated along sharp parallel contacts with reddish-grey coloured mudstones with thicknesses of less than $10 \mathrm{~m}$ (and more typically $1 \mathrm{~m}$ thick). The entire thickness of this part of the formation does not exceed approximately $300 \mathrm{~m}$.

\section{4.c.2. $A J 2$}

Higher in the Agha Jari Formation, the sandstones are thicker (up to $30 \mathrm{~m}$ ) and vary between sheet-like (Fig. 5h) and lenticular (Fig. 5i). The lenticular bodies extend laterally over distances of tens to hundreds of metres whereas the sheets may continue for several kilometres (Fig. 5h). The sandy units display impressive (mostly unidirectional) cross-stratification at a scale from $30 \mathrm{~cm}$ to several metres, with foreset angles ranging from $10^{\circ}$ to $45^{\circ}$ (Fig. 5j). These units themselves are not bioturbated, though directly adjacent thin sandstone beds may rarely show bioturbation. The sandstones are well-sorted, mature calcareous litharenites. These sandstones are separated by thick
(5-100 m) units of red silty-mudstone (Fig. 5h, i) displaying mottled textures, mud cracks and calcite nodules (Fig. 5k).

4.c.3. $A J 3$

The upper part of the Agha Jari Formation is separated into the Lahbari Member in front of the Zagros Mountain Frontal Fault, which consists of about $1600 \mathrm{~m}$ of siltstone, silty mudstone and cross-bedded, lenticular sandstone bodies (Figs 4b, 6a). The Lahbari Member is typically light coloured, poorly indurated and highly porous, and it consists of poorly sorted, low maturity sandstone with low sphericity and sub-angular grains.

\section{4.c.4. Interpretation}

The Agha Jari Formation is a synorogenic deposit produced by erosion of the uplifting Zagros mountain belt during collision. The lower part of the Agha Jari Formation (AJ1) is interpreted to be deposited on a low relief, low energy, tidal flat or estuarine environment probably influenced by both fluvial and marine processes. Similar deposits have been summarized by Reineck \& Singh (1980, pp. 315-20). In the more distal part of the foreland basin, the Agha Jari Formation is likely to be more fully marine, as indicated by the more common occurrence of homogeneous grey silty marls, possibly deposited in a delta or pro-delta setting. The second lithofacies association of the Agha Jari Formation (AJ2) is interpreted to be formed by a laterally migrating, high sinuosity (probably meandering) sandy river system developing on a flat extensive foreland plain. Sandstone bodies are interpreted to represent point bars, channels and levée deposits, whereas the red coloured silty mudstones are interpreted as adjacent flood pain deposits, which is also consistent with the presence of interpreted palaeosoil horizons. Note that this lithofacies has a broadly bimodal grain-size distribution, with sand (e.g. in channels) and silt-mud (in floodplains). In comparison to the $\mathrm{AJ} 1$ and $\mathrm{AJ} 2$, the Lahbari Member (AJ3) is interpreted to represent a lower sinuosity, more laterally confined river system depositing during a period of relatively high generation of accommodation space. This member does not exist in the internal part of the wedge-top basin.

\section{4.d. Bakhtyari Formation}

The Bakhtyari Formation is traditionally considered to be the youngest synorogenic deposit of the Zagros foreland basin (Fakhari et al. 2008). It consists mainly of massive conglomerates along with cross-bedded gravels, sandstones and mudstones (Figs 4b, 6a, b). The general thickness of the formation decreases towards the south away from Zagros Mountains where it may be several metres to $2400 \mathrm{~m}$ thick. Clasts in the Bakhtyari conglomerates are mostly derived from formations that are exposed in nearby anticlines and salt diapir structures. The transition from the Agha Jari Formation 
to the Bakhtyari Formation can be either an angular unconformity, a paraconformity or continuous (i.e. gradational). Within the Bakhtyari Formation two main lithofacies associations can be identified in the Zagros foreland basin (BK1-2).

\section{4.d.1. $B K 1$}

This lithofacies association consists of large amounts of gravels and can be regarded as the typical deposits by which the Bakhtyari Formation is known. Its thickness and make-up are extremely variable from place to place. This lithofacies association can be further divided into three sub-lithofacies associations (BK1a-c).

4.d.1.a. BKla

This sub-lithofacies association of the Bakhtyari Formation consists of massive to faintly bedded (on a scale from $3 \mathrm{~m}$ to tens of metres), coarse-grained (mostly $10-50 \mathrm{~cm}$ and sometimes over $1 \mathrm{~m}$ ), clastsupported, well-cemented, polymictic conglomerates (Fig. 51). It contains well-rounded clasts with medium sphericity and shows poor to medium sorting. Most clasts are Cretaceous and Jurassic carbonates, igneous rocks derived from the suture zone and plutonic rocks of the Sanandaj-Sirjan zone in the High Zagros. It also consists of chert clasts which are recycled from the Razak Formation in the Interior Fars and carbonates and radiolarian cherts from the Amiran and Kashkan formations in the Dezful area (Fig. 6a).

\section{4.d.1.b. BK1b}

This sub-lithofacies association of the Bakhtyari Formation consists of repeated upward-coarsening sandstones and conglomerate beds in a brownish red silty mudstone and siltstone. The thickness of conglomerate and sandstone beds is 2 to $6 \mathrm{~m}$ whereas the thickness of silty mudstones is 12 to $20 \mathrm{~m}$. These bodies tend to be lenticular and extend laterally for several hundred metres. The size of boulders is several centimetres to $20 \mathrm{~cm}$ and sometimes over $50 \mathrm{~cm}$. The sandstones are coarse grained, medium cemented, immature, poorly sorted and exhibit cross-bedding and numerous erosional surfaces. The conglomerate bodies display cross-bedding, graded bedding and clast imbrications. This sub-lithofacies association is especially well represented in the eastern part of the Dezful area where it is normally observed above BK1a (Fig. 6a, b).

\section{4.d.1.c. BK1c}

This sub-lithofacies association consists of matrix- or clast-supported, very poorly sorted, poorly cemented conglomerate or breccia containing sub-angular, low sphericity boulders $(10 \mathrm{~cm}$ to several metres in diameter) embedded within a brownish muddy silty matrix. This sub-unit consists of clasts that are mostly locally derived. This unit is only locally represented where it tends to be near the top of the Bakhtyari Formation. Its maximum thickness is in the order of 100 m (Fig. 6a, b).

\section{4.d.2. $B K 2$}

This lithofacies association, which is observed only in the High Zagros (Fakhari et al. 2008) and was not observed in our sections, consists of limestone, grey marl and occasionally sandstone which can attain a thickness of $40 \mathrm{~m}$. The limestones and marls consist of in situ corals, Miogypsinoides complanatus, Miogypsinoides sp., Subterraniphyllum thomasi, Lithophyllum sp. and Ammonia beccarii, which indicate an Early Miocene age (Elliott, 1957; Fakhari et al. 2008). This lithofacies association also includes pollen, spores and dinoflagellate cysts comprising Slowakipollenites sp., Periporopollenites sp., Monoporopollenites sp., Compositae-type pollen, Saxosporis sp., Verucatosporites sp., Homotrydium oceanicum, Hystrichokolpoma rigaudiae, Spiniferites mirabilis, Cleistosphaeridium placacanthum, Fibrocysta sp. and Deflandrea sp. (Fakhari et al. 2008).

\section{4.d.3. Interpretation}

The 'typical' Bakhtyari Formation is interpreted to be a fluvial syntectonic wedge-top basin deposit. The BK1a sub-lithofacies association is interpreted to be deposited by a very low sinuosity (probably braided) fluvial system on a wide, low relief, gravel-dominated flood plain. These extensive sheet-like deposits were probably formed by the amalgamation of smaller fans related to individual river systems draining the Zagros Mountains. The BK1b sub-lithofacies association occurs above BK1a and differs from BK1a in that it is finer grained and shows distinctly different channel versus flood plain deposits. The BK1b association most likely represents a retrograding system where the finer grained, higher sinuosity river systems of the foreland stepped backwards towards the mountain front, replacing the previously deposited braided river deposits. The cause for such a retrogression is unknown but could for example be linked to a relative base level rise. The last fan-shaped sub-lithofacies association (BK1c) is interpreted to be deposited on an alluvial fan by intermittent mass flows within an overall braided river system. The second major lithofacies association (BK2) is interpreted to be a marine deposit and represents a transgressive system related probably to a relative base level rise in the Zagros area during Early Miocene time. BK1b is overlain by BK1a or locally by BK1c, which indicates a return to the 'normal' foreland-advancing prograding braided river system. It is important to bear in mind that in the High Zagros this deposit is significantly older than typical Bakhtyari deposits exposed in more external parts of the Zagros foreland basin (Fakhari et al. 2008; Khadivi et al.2010).

\section{Discussion}

The Neogene foreland basin sediments investigated as part of our study display a broadly coarseningupward, regressive mega-cycle that presumably records 
the progressive uplift and southward migration of the Zagros mountain belt through time, as has been recognized by numerous other authors (e.g. Alavi, 2004, 2007; Fakhari et al. 2008; Heydari, 2008; Khadivi et al. 2010). This succession passes upwards from shallow marine supratidal and sabkha deposits at the base (Gachsaran Formation), into reefal carbonates (Guri Member present mainly in the eastern Zagros) and shallow marine marls (Mishan Formation) into marginal marine estuarine or tidal flat sediments (basal part of Agha Jari Formation) and finally into sand- and then gravel-dominated fluvial deposits at the top (middle-upper Agha Jari and Bakhtyari formations).

As for many other peripheral foreland basin systems (e.g. Sinclair et al. 1991; DeCelles et al. 1998; Mutti et al. 2003), this succession can be interpreted in terms of migrating depozones (see also Alavi, 2004 for the Zagros). In the Zagros, the wedge-top depozone is represented mainly by the Agha Jari and Bakhtyari formations, though in the Fars region, part of the Mishan also occupies a wedge-top position. The Zagros foredeep is represented mainly by the marine Mishan Formation, except towards the northwest (i.e. southwestern Iran and Iraq) where the Agha Jari Formation can be found in a foredeep position. The Gachsaran Formation is probably deposited in either a distal foredeep or proximal forebulge position.

It is important to emphasize that the lithofacies associations identified in the previous Section are not restricted to occurring within specific formations. For example, it is common to observe inter-fingering of the BK1b and AJ2 associations (Fig. 6b), which we interpret to indicate repeated oscillation of the braided to meandering transition through time. Although this observation makes sense in terms of depositional environments, it is problematic in terms of formation boundaries, since they are often transitional and difficult to define at an outcrop scale.

Our investigation highlights a close link between the main Neogene foreland basin deposits and the modern sedimentary environments (Fig. 7a). For example, the Bakhtyari Formation consists of mainly gravel sheets, which are interpreted to represent braided river deposits. The modern braided rivers (Fig. 3a) which are active in the Zagros foreland basin are modern analogues of the Bakhtyari Formation. Not only do the palaeoenvironments of the Bakhtyari Formation correspond to the modern braided river systems but the spatial distribution of modern braided river deposits matches the outcrops of the Bakhtyari Formation. In the downstream direction, these modern braided rivers become meandering systems (Fig. 3b), which can be considered equivalents of the Agha Jari palaeoenvironment. The modern meandering system includes sand bars and sandy channel deposits within muddy flood plain deposits, which would correspond with the crossbedded sandstone bodies and red mudstones of the Agha Jari Formation. These deposits are particularly thick in the Dezful area owing to a combination of high sediment input related to several large rivers, along with high subsidence linked with major crustal thickening in the adjacent Zagros Mountains. In comparison, these deposits are relatively thin in the Fars region where sediment supply and total subsidence are lower and the wedge-top contains a greater proportion of marine sediments. In foreland basin terminology, this region can be considered as 'under filled'. Eventually, the meandering rivers meet the Persian Gulf leading to the deposition of fine-grained argillaceous and micritic sandy sediments along its low-moderate energy northern portion. This is the site of the 'modern-day' Mishan shallow marine marls. Along the southeastern portion of the Persian Gulf is a high-energy, low water depth $(<20 \mathrm{~m})$ carbonate ramp dominated by bioclastic and oolitic sands and reefs, representing the 'Guri Member palaeoenvironment'. In the modern marine foredeep, the carbonate system only occurs to the east of the Qatar Peninsula. A similar spatial pattern is observed with the Guri Member that is thick in the Fars region but absent or very thin further to the west (e.g. in the Dezful Embayment) (Fig. 4a). Finally, the Gachsaran Formation consists of mainly evaporite sediments and coloured marls that were deposited in supratidal and sabkha type environments. Similar deposits are currently being deposited today along the southern coast of the Persian Gulf (Fig. 3d). Thus, this region can be considered a modern equivalent of the Gachsaran deposits.

Our interpretation of foreland basin depozones requires that the Zagros fold-thrust belt has migrated southwards over a distance of at least the flexural wavelength of the entire foreland basin system, because distal foredeep deposits (i.e. the Gachsaran Formation) are now exposed within the northern part of the Zagros Simply Folded Belt. Based on the present-day distance between the southern coast of the Persian coast, which is where modern equivalents of the Guri Member are found, and 'ancient' Guri Member outcrops in the Zagros Simply Folded Belt, this would require approximately $400 \mathrm{~km}$ of southward migration. Although the age of the Guri Member is not well constrained, it is thought to be approximately Middle Miocene (James \& Wynd, 1965; Kashfi, 1984; Fakhari et al. 2008). Taking an age of $15 \mathrm{Ma}$ for the Guri Member deposits in the north would imply a southward depozone migration rate of about 27

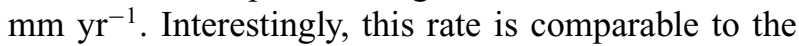
present-day motion of the Arabian plate relative to the Iranian microplate (Hessami, Nilforoushan \& Talbot, 2006; Tatar et al. 2002). An important point of this simple calculation and of this conceptual model in general is that it predicts significant differences in age (in a $\mathrm{N}-\mathrm{S}$ direction) for units that were deposited within a single depozone (Fig. 7b). This prediction is consistent with recent dating studies that have shown that the age of the Bakhtyari and Agha Jari formations between the northern and southern Zagros 

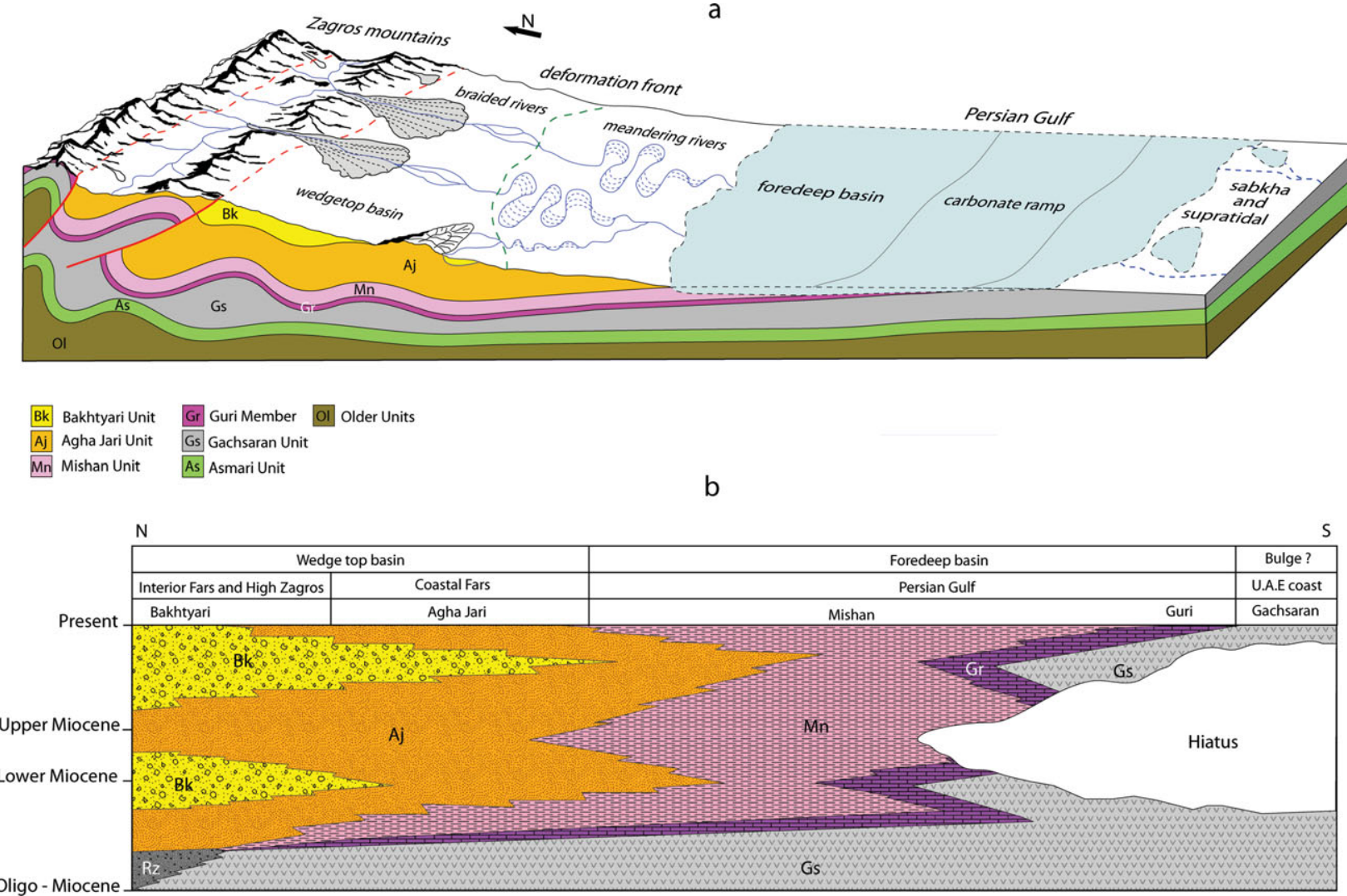

Figure 7. (Colour online) Schematic block diagram (a) and chronostratigraphic diagram (b) of the Zagros foreland basin showing the proposed link between Neogene units and the modern-day environments.

are significantly different (Homke et al. 2004; Fakhari et al. 2008; Khadivi et al. 2010).

\section{Concluding remarks}

Today the Zagros foreland exhibits a variety of different active depositional environments. From the Arabian craton towards the Zagros Mountains in the north, one typically observes a transition from sabkha and supratidal environments to carbonate ramp (distal foredeep), marine basin and coastal plain (foredeep) and finally to meandering and braided river systems (wedge-top). This horizontal transition in depozones also approximately matches the vertical passage in interpreted palaeoenvironments for sedimentary deposits of the foreland basin during the Neogene. These deposits include the mainly evaporitic Gachsaran Formation (dominantly supratidal and sabkha), the Mishan (mainly shallow to open marine marls), Agha Jari (mainly meandering river and flood plain deposits), and the Bakhtyari Formation (dominated by braided river deposits). We interpret this vertical succession to reflect the progressive evolution of the basin from distal to proximal as the mountain front and foredeep migrate southwards with time. Moreover, we suggest that the link between modern and Neogene deposits implies that the various formations are strongly diachronous. Thus, rather than being regarded as time surfaces, the Neogene formations in the Zagros are probably best thought of as diachronous depozone markers.

\section{References}

Adamia, S. A., ChKhotua, T., KeKelia, M., LoRdKipanIDZE, M. I. \& SHAVISHVILI, I. 1981. Tectonics of the Caucasus and adjoining regions: implications for evolution of the Tethys ocean. Journal of Structural Geology 3, 437-47.

AgARD, P., OMrani, J., Jolivet, L. \& Mouthereau, F. 2005. Convergence history across Zagros (Iran): constraints from collisional and earlier deformation. International Journal of Earth Sciences 94, 401-19.

AlA, M. A. 1982. Chronology of trap formation and migration of hydrocarbons in Zagros sector of southwest Iran. American Association of Petroleum Geologists Bulletin 66, 1535-41.

Ala, M. A., Kinghorn, R. R. F. \& Rahman, M. 1980. Organic geochemistry and source rock characteristics of the Zagros petroleum province, southwest Iran. Journal of Petroleum Geology 3, 61-89.

ALAVI, M. 2004. Regional stratigraphy of the Zagros fold-thrust belt of Iran and its proforeland evolution. American Journal of Science 304, 1-20.

ALAVI, M. 2007. Structures of the Zagros fold-thrust belt in Iran. American Journal of Science 307, 1064-95.

Allen, M. B. \& ARmstrong, H. A. 2008. ArabiaEurasia collision and the forcing of mid-Cenozoic global cooling. Palaeogeography, Palaeoclimatology, Palaeoecology 265, 52-8.

Allen, M. B., Blanc, E. J-P., Walker, R., Jackson, J., TAlEBian, M. \& GHASSEMI, M. R. 2006. Contrasting 
styles of convergence in the Arabia-Eurasia collision: why escape tectonics does not occur in Iran. Special Papers of the Geological Society of America 409, 57989.

Allen, M., Jackson, J. \& WAlKer, R. 2004. Late Cenozoic reorganization of the Arabia-Eurasia collision and the comparison of short-term and long-term deformation rates. Tectonics 23, C2008, doi:10.1029/2003TC001530, 16 pp.

Aubourg, C., Smith, B., Bakhtari, H. R., Guya, N. \& EsHTAGHI, A. 2008. Tertiary block rotations in the Fars arc (Zagros, Iran). Geophysical Journal International 173, 659-73.

BAHROUDI, A. \& KOYI, H. A. 2003. Effects of spatial distribution of Hormuz salt on deformation style in the Zagros fold and thrust belt: an analogue modelling approach. Journal of the Geological Society, London 160, 719-33.

BAHROUDI, A. \& KOYI, H. A. 2004. Tectono-sedimentary framework of the Gachsaran formation in the Zagros foreland basin. Marine and Petroleum Geology 21, 1295-310.

BAHRoudi, A. \& TALBOT, C. J. 2003. The configuration of the basement beneath the Zagros basin. Journal of Petroleum Geology 26, 257-82.

Ballato, P., Uba, C. E., LAndgraf, A., Strecker, M. R., Sudo, M., STOCKLI, D., Friedrich, A. \& TABATABAEI, S. H. 2011. Arabia-Eurasia continental collision: insights from late Tertiary foreland-basin evolution in the Alborz Mountains, northern Iran. Geological Society of America Bulletin 123, 10631.

BERBERIAN, M. \& KING, G. C. P. 1981. Towards a paleogeography and tectonic evolution of Iran. Canadian Journal of Earth Sciences 18, 210-85.

BEYDOUN, Z. R. 1991. Arabian plate hydrocarbon geology and potential - a plate tectonic approach. American Association of Petroleum Geologists Studies in Geology 33, $77 \mathrm{pp}$.

Beydoun, Z. R., Clarke, M. W. H. \& Stoneley, R. 1992. Petroleum in the Zagros Basin: a late Tertiary foreland basin overprinted onto the outer edge of a vast hydrocarbon-rich Paleozoic-Mesozoic passive-margin shelf. In Foreland Basins and Fold Belts (eds R. W. Macqueen \& D. A. Leckie), pp. 309-39. American Association of Petroleum Geologists Memoir no. 55.

Blanc, E. J.-P., Allen, M. B., Inger, S. \& Hassani, H. 2003. Structural styles in the Zagros simply folded zone, Iran. Journal of the Geological Society, London 160, 401-12.

BordenaVe, M. L. \& BuRWOOD, R. 1990. Source rock distribution and maturation in the Zagros orogenic belt: provenance of the Asmari and Bangestan reservoir oil accumulations. Organic Geochemistry 16, 369-87.

COLMAN-SADD, S. 1978. Fold development in Zagros simply folded belt, Southwest Iran. American Association of Petroleum Geologists Bulletin 62, 984-1003.

DeCelles, P., Gehrels, G. E., QuAde, J. \& OJHA, T. P. 1998. Eocene-early Miocene foreland basin development and the history of Himalayan thrusting, western and central Nepal. Tectonics 17, 741-65.

DeCelles, P. G. \& GILES, K. 1996. Foreland basin systems. Basin Research 8, 105-23.

DunNington, H. V. 1968. Salt-tectonic features of Northern Iraq. Special Papers of the Geological Society of America 88, 183-227.

ElliotT, G. F. 1957. Subterraniphyllum, a new Tertiary calcareous algae. Palaeontology 1, 73-5.
EMERY, K. O. 1956. Sediments and water of Persian Gulf. American Association of Petroleum Geologists Bulletin 40, 2354-83.

FAKHARI, M. D., AXEN, G. J., HORTON, B. K., HASSANZADEH, J. \& AMINI, A. 2008. Revised age of proximal deposits in the Zagros foreland basin and implications for Cenozoic evolution of the High Zagros. Tectonophysics 451, 170 85.

FALCON, N. L. 1974. Southern Iran: Zagros Mountains. In Mesozoic-Cenozoic Orogenic Belts (ed. A. M. Spencer), pp. 199-211. Geological Society of London, Special Publication no. 4.

FAVRE, G. 1974. The post Asmari Formations of southwest Iran. National Iranian Oil Company, Report 1220.

Foda, M. A., Khaiaf, F. I. \& Al-Kadi, A. S. 1985. Estimation of dust fallout and rates in the northern Arabian Gulf. Sedimentology 32, 595-603.

Fryberger, S. G., Al-Sari, A. M. \& Clisham, T. J. 1983. Eolian dune, interdune sand sheet and siliciclastic sabkha sediments of an offshore prograding sand sea, Dhahran, Saudi Arabia. American Association of Petroleum Geologists Bulletin 67, 280-312.

Ghasemi-Nejad, E., Head, M. \& NAderi, M. 2009. Palynology and petroleum potential of the Khazhdumi Formation (Cretaceous: Albian-Cenomanian) in the South Pars field, northern Persian Gulf. Marine and Petroleum Geology 26, 805-16.

Hessami, K., Nilforoushan, F. \& TAlbot, C. J. 2006. Active deformation within the Zagros Mountains deduced from GPS measurements. Journal of the Geological Society, London 163, 143-8.

HEYDARI, E. 2008. Tectonics versus eustatic control on supersequences of the Zagros Mountains of Iran. Tectonophysics 451, 56-70.

Homke, S., Verges, J., GARCES, M., EMAMI, H. \& KARPUZ, R. 2004. Magnetostratigraphy of Miocene-Pliocene Zagros foreland deposits in the front of the Push-e Kush arc (Lurestan Province, Iran). Earth and Planetary Science Letters 225, 397-410.

Houbolt, J. J. H. C. 1957. Surface sediments of the Persian Gulf near the Qatar Peninsula. Published Ph.D. thesis. University of Utrecht. The Hague: Mouton and Co. $113 \mathrm{pp}$.

Jahani, S., Callot, J. P., Letouzey, J. \& Lamotte, D. F. 2009. The eastern termination of the Zagros foldthrust belt, Iran: structures, evolution and relationships between salt plugs, folding and faulting. Tectonics 28, TC6004, doi:10.1029/2008TC002418, 22 pp.

JAMES, G. A. \& WYND, J. G. 1965. Stratigraphic nomenclature of Iranian Oil Consortium agreement area. American Association of Petroleum Geologists Bulletin 49, 2182-245.

KASHFI, M. 1984. Evidence for vertical movement in the southern part of the Zagros geosynclines, Iran. Journal of Petroleum Geology 7, 87-96.

Kent, P. E. 1970. The salt plugs of the Persian Gulf region. Leicester Literary and Philosophical Society Transactions 64, 56-88.

Khadivi, S., MOUTHEREAU, F., LARRASOAÑA, J. C., VERGÉS, J., LaCOMBE, O., Khademi, E., Beamud, E., MelinteDOBRINESCU, M. \& SUC, J.-P., 2010. Magnetochronology of synorogenic Miocene foreland sediments in the Fars arc of the Zagros Folded Belt (SW Iran). Basin Research 22, 918-32.

KoOP, W. \& STONELEY, R. 1982. Subsidence history of the Middle East Zagros basin, Permian to Recent. Philosophical Transactions of Royal Society of London 305, 149-68. 
Lacombe, O., Amrouch, K., Mouthereau, F. \& Dissez, L. 2007. Calcite twinning constraints on late Neogene stress patterns and deformation mechanisms in the active Zagros collision belt. Geology 35, 263-6.

Lacombe, O., Mouthereau, F., Kargar, S. \& Meyer, B. 2006. Late Cenozoic and modern stress fields in the western Fars (Iran): implications for the tectonic and kinematic evolution of Central Zagros. Tectonics 25, TC1003, doi:10.1029/2005TC001831, 27 pp.

MCQUARRIE, N. 2004. Crustal scale geometry of the Zagros fold-thrust belt, Iran. Journal of Structural Geology 26, 519-35.

Molinaro, M., Zeyen, H. \& Laurencin, X. 2005. Lithospheric structure beneath the south-eastern Zagros mountains, Iran: recent slab break off? Terra Nova 17, $1-6$.

MotiEI, H. 1993. Stratigraphy of Zagros. Tehran: Geological Survey of Iran, $536 \mathrm{pp}$.

Mouthereau, F., Lacombe, O. \& Meyer, B. 2006. The Zagros folded belt (Fars, Iran): constraints from topography and critical wedge modeling. Geophysical Journal International 165, 336-56.

Mouthereau, F., Tensi, J., Bellahsen, N., Lacombe, O., De Boisgrollier, T. \& KARGAR, S. 2007. Tertiary sequence of deformation in a thin-skinned/thick-skinned collision belt: the Zagros Folded Belt (Fars, Iran). Tectonics 26, TC5006, doi:10.1029/2007TC002098, $28 \mathrm{pp}$.

Mutti, E., Tinterri, R., Benevelli, G., Biase, D. \& CavanNA, G. 2003. Deltaic, mixed and turbidite sedimentation of ancient foreland basins. Marine and Petroleum Geology 20, 733-55.

NADJAFI, M., MahboubI, A., MossaVi-Harami, R. \& MIRZAEE, R. 2004. Depositional history and sequence stratigraphy of outcropping Tertiary carbonates in the Jahrom and Asmari formations, Shiraz area (SW Iran). Journal of Petroleum Geology 27, 179-90.

Nilforoushan, F., Masson, F., Vernant, P., Vigny, C., MARTINOD, J., ABBASSI, M., NANKALI, H., HATZFELD, D., Bayer, R., Tavakoli, F., Ashtiani, A., DoerFlinger, E., DAignieres, M., Collard, P. \& Chery, J. 2003. GPS network monitors the Arabia-Eurasia collision deformation in Iran. Journal of Geodesy 77, 411-22.

O'Brien, C. A. E. 1957. Salt diapirism in South Persia. Geologie en Mijnbouw 19, 337-76.

Purser, B. H. \& SEIBOLD, E. 1973. The principal environmental factors influencing Holocene sedimentation and diagenesis in the Persian Gulf. In The Persian Gulf Holocene Carbonate Sedimentation and Diagenesis in a Shallow Epicontinental Sea (ed. B. H. Purser), pp. 1-9. New York: Springer-Verlag.

RAZIN, P., TAATI, F. \& VAN BUCHEM, F. S. P. 2010. Sequence stratigraphy of Cenomanian-Turonian carbonate platform margins (Sarvak formation) in the High Zagros, SW Iran: an outcrop reference model for the Arabian plate. In Mesozoic and Cenozoic Carbonate Systems of the Mediterranean and the Middle East: Stratigraphic and Diagenetic Reference Models (eds F. S. P. van Buchem, K. D. Gerdes \& M. Esteban), pp. 187218. Geological Society of London, Special Publication no. 329.

READING, H. G. 1986. Sedimentary Environments and Facies. Blackwell Scientific Publications, 615 pp.

Reilinger, R., McClusky, S., Vernant, F., LaWrence, S., ERgintav, S., CAKMAK, R., OZEnER, H., KaDirov, F., Guliev, I., Stepanyan, R., NADARiYa, M., Hahubia, G., Mahmoud, S., SAKR, K., ArRajehi, A.,
Paradissis, D., Al-Aydrus, A., Prilepin, M., GuseVA, T., Evren, E., DMitrotsa, A., Filikov, S. V., Gomez, F., AL-GHAZZI, R. \& KARAM, G. 2006. GPS constraints on continental deformation in the Africa-Arabia-Eurasia continental collision zone and implications for the dynamics of plate interactions. Journal of Geophysical Research 111, B05411, doi:10.1029/2005JB004051, $26 \mathrm{pp}$.

ReINECK, H. E. \& Singh, I. B. 1980. Depositional Sedimentary Environments. New York: Springer-Verlag, $551 \mathrm{pp}$.

Saura, E., Vergés, J., Homke, S., Blanc, E., SerraKiel, J., Bernaola, G., Casciello, E., Fernández, N., Romaire, I., CAsini, G., Embry, J. C. Sharp, I. R. \& HUNT, D. W. 2011. Basin architecture and growth folding of the NW Zagros early foreland basin during the late Cretaceous and early Tertiary. Journal of the Geological Society, London 168, 23550.

SzaBo, F. \& KheradPIR, A. 1978. Permian and Triassic stratigraphy, Zagros basin, south-west Iran. Journal of Petroleum Geology 1, 57-82.

SENGOR, A. M. C. 1990. A new model for the late PalaeozoicMesozoic tectonic evolution of Iran and implications for Oman. In The Geology and Tectonics of the Oman Region (eds A. H. F. Robertson, M. P. Searle, \& A. C. Ries), pp. 797-831. Geological Society of London, Special Publication no. 49.

SEPEHR, M. \& COSGROVE, J. W. 2004. Structural framework of the Zagros fold thrust belt, Iran. Marine and Petroleum Geology 21, 829-43.

SEPEHR, M. \& COSGROVE, J. W. 2005. Role of the Kazerun Fault zone in the formation and deformation of the Zagros Fold-Thrust Belt, Iran. Tectonics 24, TC5005, doi:10.1029/2004TC001725, 13 pp.

SETUDEHNIA, A. 1972. International stratigraphic Lexicon of Iran: South-west Iran. International Union of Geological Sciences 3, 289-376.

SETUDEHNIA, A. 1978. The Mesozoic sequence in south-west Iran and adjacent areas. Journal of Petroleum Geology 1, 3-42.

SHERKATI, S. \& LETOUZEY, J. 2004. Variation of structural style and basin evolution in the central Zagros (Izeh zone and Dezful embayment), Iran. Marine and Petroleum Geology 21, 535-54.

Sinclair, H. D., CoAKley, B. J., Allen, P. A. \& Watts, A. B. 1991. Simulation of foreland basin stratigraphy using a diffusion model of mountain belt uplift and erosion: an example from the central Alps, Switzerland. Tectonics 10, 599-620.

STÖCKLIN, J. 1968. Structural history and tectonics of Iran: a review. American Association of Petroleum Geologists Bulletin 52, 1229-58.

STÖCKLIN, J. 1974. Possible ancient continental margins in Iran. In The Geology of Continental Margins (eds C. A. Burk \& C. L. Drake), pp. 873-87. New York: SpringerVerlag.

STÖCKLIN, J. 1977. Structural correlation of the Alpine ranges between Iran and Central Asia. Mémoire HorsSérie de la Société Géologique de France 8, 333-53.

TALBOT, C. J. \& ALAVI, M. 1996. The past of a future syntaxis across the Zagros. In Salt Tectonics (eds G. I. Alsop, D. J. Blundell \& I. Davison), pp. 89-109. Geological Society of London, Special Publication no. 100.

TAtar, M., HatzFeld, D., MartinOd, J., WalPersdolf, A., Ghafori-Ashtiany, M. \& Chery, J. 2002. The present-day deformation of the central Zagros from GPS measurements. Geophysical Research Letters 29, 10-13 
VAZIRI-MOghaddam, H., Kimiagari, M. \& TAHERI, A. 2006. Depositional environment and sequence stratigraphy of the Oligo-Miocene Asmari formation in SW Iran. Facies 52, 41-51.

Vernant, P. H., Nilforoushan, N., HatzFeld, D., ABbassi, M. R., VignY, C., Masson, F., NANKali, H., Martinod, J., Ashtiani, A., Bayer, R., TAVAKoli, F. \& CHÉRY, J. 2004. Present-day crustal deformation and plate kinematics in the Middle East constrained by GPS measurements in Iran and northern Oman. Geophysical Journal International 157, 381-98.

Walpersdorf, A., HatzFeld, D., NANKali, H., TAVAKOli, F., Nilforoushan, F., TATAR, M., VERnANT, P., CHÉRY, J. \& MASSON, F. 2006. Difference in the GPS deformation pattern of North and Central Zagros (Iran). Geophysical Journal International 167, 1077-88. 